\title{
STRUKTUR VEGETASI DAN SIMPANAN KARBON HUTAN RAKYAT DESA SAMBAK, MAGELANG, JAWA TENGAH
}

\section{Vegetation structure and carbon stock of Private Forest, Sambak Village, Magelang, Central Java}

\author{
Rizmoon Nurul Zulkarnaen \\ Pusat Penelitian Konservasi Tumbuhan dan Kebun Raya, Lembaga Ilmu Pengetahuan Indonesia \\ Jl. Ir. H. Juanda No.13 Kota Bogor, Jawa Barat, Indonesia 16003 \\ Email: rizmoon.zulkar@gmail.com
}

Diterima/Received: 24 Oktober 2019; Disetujui/Accepted: 29 Juni 2020

\begin{abstract}
The Private forest is a forest developed on land owned by the private and not in a forest area. The diversity of plants that make up private forests depends on the interests of each landowner. One of the sustainable private forest practices is in Sambak Village, Kajoran District, Magelang Regency. It can be seen from the high level of population participation in planting forest plants on their lands. However, there is little information about the constituent vegetation planted in private forest practice. Therefore, this research was conducted to reveal private forest practices in Sambak Village. In addition, the calculation of carbon stock in private forests is also carried out to reveal the role of private forests in carbon absorption. The data collection technique used the transect method with an observation plot measuring $20 \times 20 \mathrm{~m}$ with $50 \mathrm{~m}$ in the distance between plots. The method of calculating carbon stock used a non-destructive method by estimating carbon stock based on tree diameter and height. The composition of the plants that make up the private forest vegetation consists of 24 species from 16 families. Sengon dominated the vegetation that makes up the private forest. These results were following the calculation of the highest importance value index achieved by Sengon $(70,67)$, Mahoni $(52,18)$, Kelapa $(37,53)$, and Nangka $(25,21)$. The total carbon stock calculation has amounted to 24,53 ton $\mathrm{C} / \mathrm{ha}$ and $\mathrm{CO}_{2}$ absorption of 90,05 ton $\mathrm{CO}_{2} /$ ha. The highest carbon stock in the private forest of Sambak Village was Pinus 10,22 ton C/ha.
\end{abstract}

\section{Keywords: private forest, vegetation structure, carbon stock}

\begin{abstract}
Abstrak
Hutan rakyat adalah hutan yang dikembangkan di lahan milik masyarakat dan bukan di kawasan hutan. Keragaman vegetasi penyusun hutan rakyat bergantung pada kepentingan masing-masing pemilik lahan. Salah satu praktik hutan rakyat yang lestari berada di Desa Sambak, Kecamatan Kajoran, Kabupaten Magelang. Hal tersebut terlihat dari tingkat partisipasi penduduk yang tinggi dalam menanam tanaman berkayu keras di lahanlahan mereka. Namun demikian, informasi tentang vegetasi-vegetasi penyusun yang ditanam dalam praktik hutan rakyat tersebut masih sedikit. Oleh karena itu, penelitian ini dilakukan dalam upaya mengungkap praktik hutan rakyat di Desa Sambak. Selain itu, penghitungan simpanan karbon di hutan rakyat tersebut juga dilakukan dalam upaya mengungkap peranan hutan rakyat dalam penyerapan karbon. Teknik pengumpulan data menggunakan metode transek dengan plot pengamatan berukuran $20 \times 20 \mathrm{~m}$ dengan jarak antar plot $50 \mathrm{~m}$. Metode penghitungan simpanan karbon menggunakan metode non-destruktif yaitu dengan cara menaksir simpanan karbon berdasarkan diameter dan tinggi pohon. Komposisi penyusun vegetasi hutan rakyat tersebut terdiri atas 24 spesies dari 16 famili. Vegetasi penyusun hutan rakyat tersebut didominasi oleh Sengon. Hasil tersebut sesuai dengan penghitungan indeks nilai kepentingan tertinggi yang dicapai oleh Sengon $(70,67)$,
\end{abstract}


Mahoni $(52,18)$, Kelapa $(37,53)$, dan Nangka $(25,21)$. Hasil perhitungan total simpanan karbon di hutan rakyat Sambak sebesar 24,53 ton $\mathrm{C} /$ ha dan serapan $\mathrm{CO}_{2}$ sebesar 90,05 ton $\mathrm{CO}_{2} /$ ha. Adapun simpanan karbon tertinggi dimiliki oleh Pinus 10,22 ton C/ha dan Kelapa 6,77 ton C/ha.

Kata kunci: hutan rakyat, struktur vegetasi, simpanan karbon

\section{PENDAHULUAN}

Hutan adalah suatu kesatuan ekosistem berupa hamparan lahan berisi sumber daya alam hayati yang didominasi pepohonan dalam persekutuan alam lingkungannya yang satu dengan lainnya tidak dapat dipisahkan. Berdasarkan status lahannya, hutan terbagi menjadi dua macam, yaitu hutan negara dan hutan hak. Salah satu contoh hutan hak yaitu hutan rakyat (private forest) dimana hutan tersebut berada pada tanah yang dibebani hak milik lazim (Undang-Undang No 41 Tahun 1999).

Keberadaan hutan rakyat merupakan salah satu alternatif pemecahan masalah terhadap tekanan sumber daya hutan/kawasan hutan (Alviya et al. 2007). Keberadaan hutan rakyat sudah dikenal sejak lama oleh masyarakat Indonesia, khususnya di Jawa (Simon 2001; Jariyah \& Wahyuningrum 2008). Hutan rakyat memiliki potensi besar sebagai penyedia kayu, terutama kayu bangunan dan furnitur. Produksi kayu dari hutan rakyat di Jawa diperkirakan lebih dari 5 juta $\mathrm{m}^{3}$ /ha (Suprapto 2010; Widiarti 2015). Hal tersebut memberikan dampak ekonomi yang signifikan terhadap perekonomian masyarakat (Awang et al. 2007). Adapun fungsi ekonomi hutan rakyat akan terlihat dari teknik pengelolaanya, seperti teknik agroforestri dengan mengkombinasikan tanaman hutan dengan tanaman perkebunan (Zulkarnaen \& Suryanto 2013; Sudomo \& Hani 2014; Irmasari et al. 2018). Namun, ada juga hutan rakyat yang ditanami dengan tanaman hutan saja (kayu keras) (Suprapto 2010). Secara ekologi, fungsi hutan rakyat yang jelas terlihat langsung adalah kemampuannya dalam menyimpan cadangan karbon (Zahabu 2006; Nair et al. 2009; Purwanto \& Silaban 2011; Purwanto et al. 2012; Indrajaya \& Sudomo 2016; Rizki et al. 2016; Ivando et al. 2019). Zahabu (2006) mengungkapkan bahwa kawasan hutan yang dikelola masyarakat di Desa Handei, Tanzania mempunyai simpanan karbon sebanyak 77,4 ton C/ha. Selain itu, fungsi ekologi lainnya dari hutan rakyat antara lain penjaga siklus air dan mengurangi dampak erosi dan banjir (Ulfah et al. 2017).

Penelitian-penelitian yang berhubungan hutan rakyat sudah banyak dilakukan di Indonesia, khususnya di Jawa (Suprapto 2010; Purwanto \& Silaban 2011; Purwanto et al. 2012). Adapun lokasi dalam penelitian ini dilakukan di Desa Sambak, Kab. Magelang, Prov. Jawa Tengah karena desa tersebut telah menjadi salah satu desa yang berhasil dalam program PHBM (Pengelolaan Hutan Bersama Masyarakat) di Kabupaten Magelang. Selain itu, desa tersebut juga terpilih sebagai model (pilot village) pada program nasional pengelolaan DAS (Daerah Aliran Sungai) Mikro.

Analisis potensi ekologi hutan rakyat di Desa Sambak belum pernah dilaporkan secara detail, termasuk kajian penyusun vegetasi dan kemampuannya dalam penyerapan karbon belum pernah diungkap. Oleh karena itu, penelitian ini bertujuan untuk mengetahui komposisi penyusun vegetasi hutan rakyat Desa Sambak dan mengukur potensi simpanan karbon di hutan rakyat Desa Sambak.

\section{BAHAN DAN METODE}

\section{Lokasi dan waktu}

Penelitian dilakukan di hutan rakyat di Desa Sambak, Kecamatan Kajoran, Kabupaten Magelang, Jawa Tengah (Gambar 1). Penelitian dilakukan pada bulan Februari-Maret 2013. Secara deskriptif, Desa Sambak merupakan daerah dengan area pegunungan di lereng gunung Sumbing yang memiliki ketinggian 438-750 m dpl. Berdasarkan laporan Pemerintah Desa Sambak tahun 2004, desa ini memiliki wilayah seluas 334,5 ha yang terdiri atas 132 ha berupa lahan persawahan, 43,5 ha kebun campur, 66,6 ha tegalan, 110 ha hutan rakyat, dan 80 ha hutan negara. 


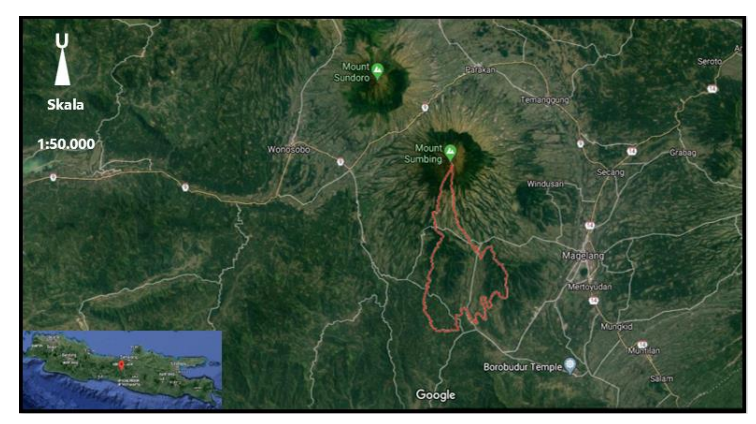

Gambar 1. Lokasi penelitian di Desa Sambak, Kecamatan Kajoran, Kabupaten Magelang, Jawa Tengah

Secara geografis, Desa Sambak berada pada titik koordinat $110^{\circ} 04^{\prime} 14^{\prime \prime}$ BT dan $07^{\circ} 30^{\prime} 12^{\prime \prime}$ LS. Menurut klasifikasi Schmidt-Ferguson, desa ini memiliki iklim tipe $\mathrm{C}$ (agak basah). Suhu udara antara $20^{\circ} \mathrm{C}$ dan $30^{\circ} \mathrm{C}$ dengan curah hujan rata-rata sebesar $124 \mathrm{~mm} /$ bulan dengan curah hujan tertinggi mencapai $2987 \mathrm{~mm} /$ tahun.

\section{Pengambilan contoh}

Contoh diambil dengan metode transect purposive sampling dengan membangun plot pengamatan berukuran 20x20 m dengan jarak antar plot $50 \mathrm{~m}$ (Mueller-Dombois \& Ellenberg 1974) (Gambar 2). Jumlah plot pengamatan yang dibuat berjumlah 16 plot ukur pengamatan. Penentuan jumlah plot pengamatan tidak ditentukan sebelumnya. Jumlah tersebut merupakan hasil transek yang memotong jalur hutan rakyat (berbatasan dengan lahan persawahan) sampai dengan kawasan hutan yang dikelola Perum Perhutani. Adapun lintasan transek hutan rakyat secara berurutan meliputi lahan pekarangan, lahan kering, lahan wanatani, lahan basah (sawah), sungai, lahan basah (sawah), lahan wanatani, lahan kering, dan hutan pinus (hutan negara).

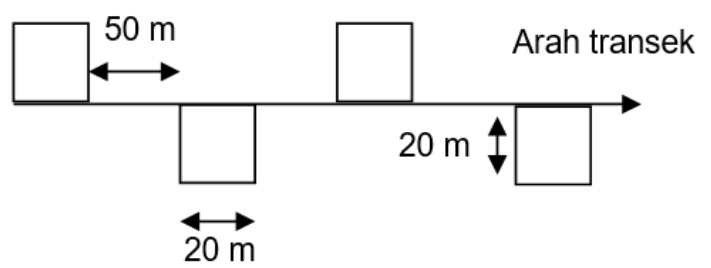

Gambar 2. Skema pembuatan plot pengamatan Inventarisasi vegetasi dilakukan secara menyeluruh dengan variabel pengamatan meliputi nama spesies, diameter, dan tinggi. Kriteria vegetasi yang diinventarisasi dibedakan berdasarkan klasifikasi tingkat pertumbuhan (Tabel 1).
Tabel 1. Klasifikasi dan kriteria pengukuran inventarisasi vegetasi (Daniel et al. 1979)

\begin{tabular}{|c|c|c|}
\hline No & Klasifikasi & Kriteria \\
\hline 1. & Pohon & Diameter batang $\geq 20 \mathrm{~cm}$ \\
\hline 2. & Tiang & Diameter batang $10-<20 \mathrm{~cm}$ \\
\hline 3. & Pancang & $\begin{array}{l}\text { Permudaan yang tingginya } 1,5 \\
\mathrm{~m} \text { dan lebih sampai diameter } \\
<10 \mathrm{~cm}\end{array}$ \\
\hline 4. & Semai & $\begin{array}{l}\text { Anakan pohon sampai tinggi } \\
\text { hingga } 1,5 \mathrm{~m}\end{array}$ \\
\hline
\end{tabular}

\section{Analisis Data}

a. Indeks Nilai Kepentingan (INP)

Penggambaran pengelolaan hutan rakyat menggunakan analisis deskriptif. Parameter vegetasi yang dianalisis meliputi spesies, tinggi dan diameter pohon. Parameter tersebut dianalisis untuk mengetahui komposisi vegetasi hutan dengan menggunakan Indeks Nilai Kepentingan (Importance Value Index) yang dapat menggambarkan kerapatan, penyebaran, penguasaan, dan peranan spesies. INP merupakan sebuah parameter kuantitatif yang dapat dipakai untuk menyatakan tingkat dominansi suatu spesies (Soegianto 1994). Penghitungan INP dilakukan dengan mengacu pada rumus yang dikemukakan oleh Mueller-Dombois \& Ellenberg (1974), yaitu:

$$
\begin{aligned}
& \text { INP = KR + FR + D } \mathbf{R} \\
& \text { Keterangan: } \\
& \begin{aligned}
\text { INP } & =\text { Indeks nilai kepentingan } \\
\mathrm{KR} & =\text { Kerapatan relatif, } \\
& =\frac{\text { Kerapatan spesies }}{\text { Kerapatan semua spesies }} \times 100 \% \\
\mathrm{FR} & =\text { Frekuensi relatif, } \\
& =\frac{\text { Frekuensi spesies }}{\text { Frekuensi semua spesies }} \times 100 \% \\
\mathrm{DR} & =\text { Dominansi relatif, } \\
& =\frac{\text { Dominansi spesies }}{\text { Dominansi semua spesies }} \times 100 \%
\end{aligned}
\end{aligned}
$$

\section{b. Analisis potensi simpanan karbon di hutan rakyat Desa Sambak}

Penghitungan simpanan karbon hutan dapat dilakukan berbagai cara tergantung tujuannya, di antaranya adalah penghitungan karbon pohon, penghitungan biomasa bawah permukaan tanah (akar), penghitungan karbon tumbuhan bawah, penghitungan karbon seresah, penghitungan karbon untuk nekromas kayu, dan penghitungan karbon tanah (Wibowo et al. 2013). Untuk menaksir potensi simpanan karbon hutan rakyat Desa Sambak digunakan pendekatan penghitungan 
karbon pohon (above ground). Penghitungan karbon pohon dilakukan melalui dua langkah, yaitu penghitungan biomasa pohon dan penghitungan simpanan karbon. Langkah-langkah tersebut diuraikan secara singkat sebagai berikut.

\section{Penghitungan biomasa pohon}

Pengukuran biomasa pohon menggunakan metode non-destructive yang dilakukan tanpa memanen pohon. Parameter yang digunakan yaitu diameter dan tinggi (Jones 1979; Hairiah et al. 2011). Rumus allometrik yang digunakan mengikuti persamaan allometrik yang sesuai dengan spesies masing-masing (Tabel 2) (Ketterings et al. 2001; Nugroho 2014; Hairiah \& Rahayu 2007).

Tabel 2. Persamaan allometrik untuk penaksiran total biomassa

\begin{tabular}{lll}
\hline No & Nama & Persamaan allometrik \\
\hline 1. & Mahoni & $\mathrm{BK}=0,902\left(\mathrm{D}^{2} \mathrm{H}\right)^{0,08}$ \\
2. Jati & $\mathrm{BK}=0,015\left(\mathrm{D}^{2} \mathrm{H}\right)^{1,08}$ \\
3. & Sengon & $\mathrm{BK}=0,020\left(\mathrm{D}^{2} \mathrm{H}\right)^{0,93}$ \\
4. $\quad$ Kopi & $\mathrm{BK}=0,281(\mathrm{D})^{2,06}$ \\
5. Palem & $\mathrm{BK}=\mathrm{EXP}(-2,134) \mathrm{D}^{2,530}$ \\
6. Kakao & $\mathrm{BK}=0,1208(\mathrm{D})^{1,98}$ \\
7. Pohon bercabang & $\mathrm{BK}=0,11 \rho(\mathrm{D})^{2,62}$ \\
8. Pohon tidak & $\mathrm{BK}=\pi \rho \mathrm{D}^{2} \mathrm{H} / 40$ \\
& \\
\hline Keterangan: & \\
$\mathrm{BK}=$ Biomassa (Kg/pohon) & \\
$\mathrm{D}=$ Diameter pohon & \\
$\mathrm{H}=$ Tinggi pohon & \\
$\rho \quad=$ Berat jenis pohon &
\end{tabular}

\section{Penghitungan simpanan karbon}

Penghitungan simpanan karbon yang tersimpan dalam tegakan merupakan konversi dari penghitungan biomassa yang diperoleh dan mengalikannya dengan faktor koreksi $(0,5)$ (IPCC 2006). Simpanan karbon dalam hutan diduga dengan menggunakan rumus:

\section{$C=W \times 0,5$}

Keterangan:

$\mathrm{C}=$ Jumlah simpanan karbon (ton $\mathrm{C} / \mathrm{ha}$ )

$\mathrm{W}=$ Biomassa (ton/ha).

Kemudian, hasil penghitungan $\mathrm{C}$ dikonversi ke dalam bentuk $\mathrm{CO}_{2}$ dengan mengalikan hasil penghitungan $\mathrm{C}$ tersebut dengan faktor konversi sebesar 3,67 (Mirbach 2000):
$\mathrm{WCO}_{2}=\mathrm{C} \times 3,67$

Keterangan:

$\mathrm{C}=$ Jumlah simpanan karbon (ton $\mathrm{C} / \mathrm{ha}$ )

$\mathrm{WCO}_{2}=$ Jumlah $\mathrm{CO}_{2}$ terserap (ton $\mathrm{CO}_{2} /$ ha)

\section{HASIL DAN PEMBAHASAN}

\section{Struktur vegetasi hutan rakyat Desa Sambak}

Gambaran struktur vegetasi hutan rakyat Desa Sambak diwakili oleh 325 individu yang terbagi ke dalam kategori pohon, tiang, pancang, dan semai. Struktur vegetasi hutan rakyat Desa Sambak didominasi kategori tiang (>200 individu). Kategori pohon hanya ditemukan kurang dari 100 individu, sedangkan katagori pancang dan semai kurang dari 15 individu (Gambar 3). Hasil tersebut mengindikasikan bahwa hutan rakyat Desa Sambak dalam periode tersebut termasuk mempunyai umur relatif muda. Informasi tersebut juga menunjukkan proses suksesi yang masih terus berjalan. Hal ini juga dapat dilihat dari sejarah pembangunan hutan rakyat di Desa Sambak yang baru dimulai pada tahun 2008 dengan visi desa agro wana wisata (RPJMD Sambak 2004). Adapun dominasi pancang dan semai yang relatif sedikit menunjukkan sudah tidak ada upaya pengayaan.

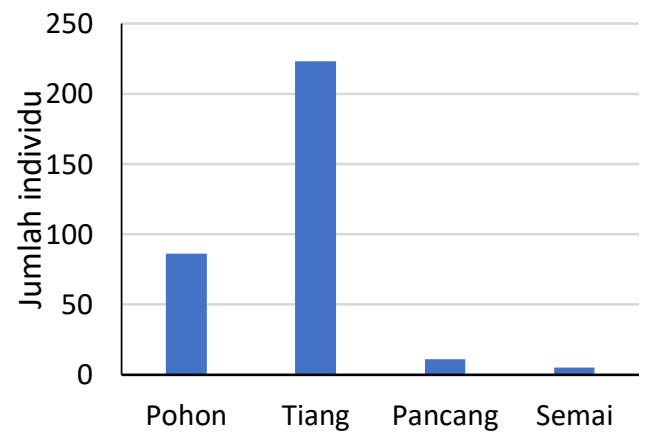

Gambar 3. Struktur vegetasi dalam tingkat pohon, tiang, pancang, dan semai

Komposisi vegetasi hutan rakyat Desa Sambak terdiri dari 24 spesies yang tercakup dalam 16 famili (Tabel 3). Hasil perhitungan INP menggambarkan tanaman yang mendominasi di hutan rakyat Desa Sambak. Sengon (Falcataria falcata) mendominasi hutan rakyat Desa Sambak dengan nilai INP 70,67\%. Nilai tersebut mengindikasikan bahwa sengon merupakan spesies tanaman yang banyak dipilih sebagai penyusun hutan rakyat di Desa Sambak. Oleh karena itu, spesies tersebut mempunyai nilai relatif kerapatan 


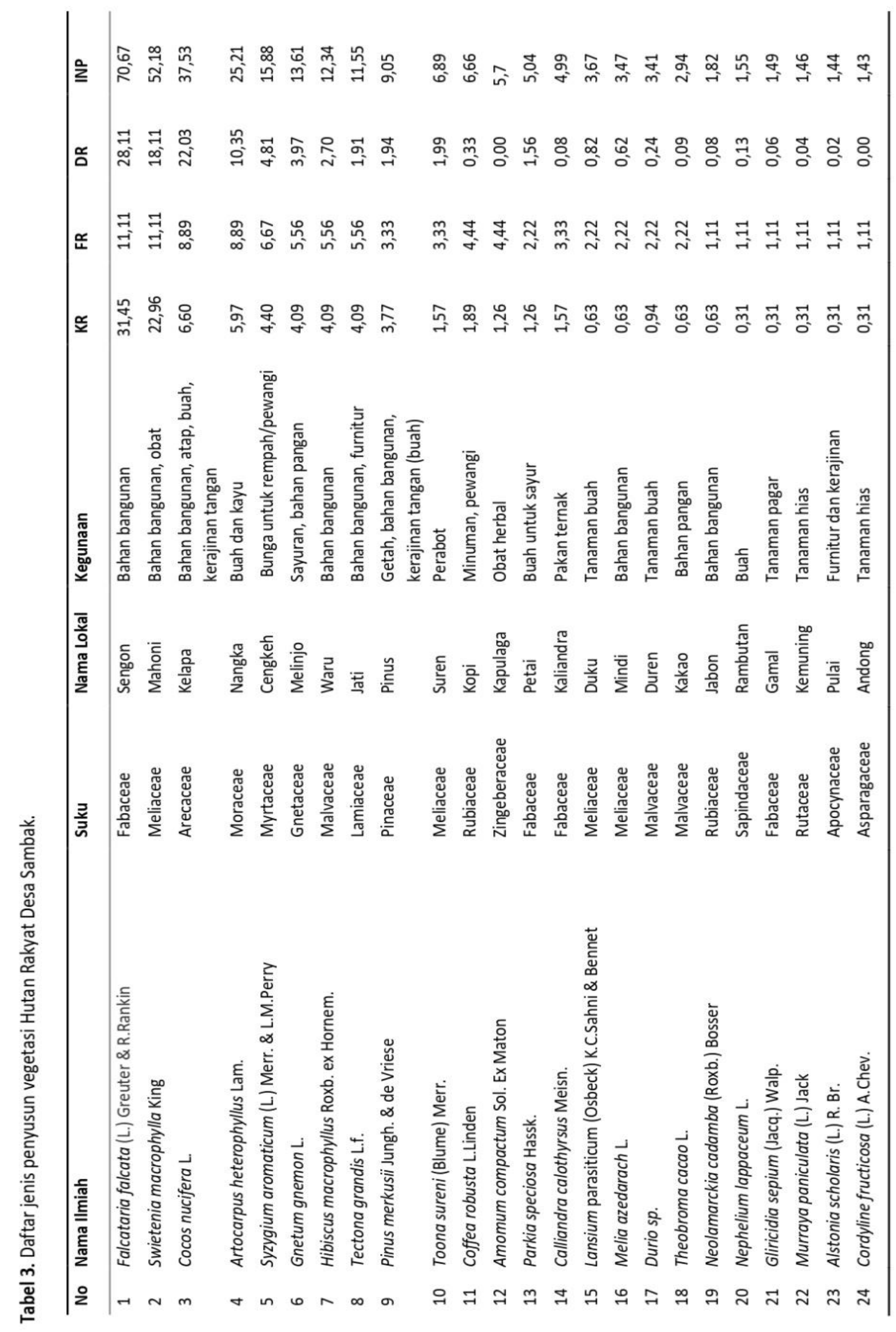


dan dominansi yang lebih tinggi di antara spesiesspesies lainnya.

Mahoni (Swietenia macrophylla) menempati urutan kedua setelah sengon. Hal tersebut mengindikasikan bahwa mahoni merupakan spesies tanaman yang relatif dapat berkembang dengan baik di dalam hutan rakyat, sehingga dipilih oleh petani. Selain itu, data vegetasi penyusun hutan rakyat Desa Sambak juga menunjukkan bahwa sebaran pohon penghasil buah merata dalam setiap plot pengamatan. Hal ini mengindikasikan bahwa masyarakat dalam praktiknya tetap mengkombinasikan tanaman penghasil kayu dengan tanaman perkebunan/pertanian berupa pohon buah-buahan.

Kondisi yang sama juga ditemukan pada pengelolaan hutan rakyat di Tasikmalaya yang didominasi oleh sengon dan mahoni (Siarudin \& Indrajaya 2014), sedangkan pada hutan rakyat di Nglanggeran, Gunung Kidul yang mendominasi adalah mahoni (Purwanto et al. 2012). Fenomena pemilihan kedua spesies tersebut untuk penyusun vegetasi hutan rakyat, khususnya di Jawa disebabkan karena spesies tersebut mempunyai daur yang relatif pendek, yaitu berkisar antara 7-12 tahun (Jariyah \& Wahyuningrum 2008; Widiarti \& Prajadinata 2008).

\section{Potensi simpanan karbon hutan rakyat Desa Sambak}

Potensi simpanan karbon hutan rakyat Desa Sambak tertinggi diperoleh oleh Pinus, Kelapa, dan Cengkeh (Gambar 4). Nilai simpanan karbon pada Pinus diketahui berjumlah 10,22 ton $\mathrm{C} /$ ha, Kelapa berjumlah 6,77 ton $\mathrm{C} / \mathrm{ha}$, dan Cengkeh berjumlah 2,004 ton $\mathrm{C} / \mathrm{ha}$. Adapun total potensi simpanan karbon berjumlah 24,53 ton $\mathrm{C} / \mathrm{ha}$.

Nilai potensi simpanan karbon tersebut relatif lebih kecil jika dibandingkan dengan beberapa praktik hutan rakyat lainnya seperti di hutan rakyat Desa Nglanggeran, Gunung Kidul dengan potensi biomassa dan simpanan karbon sebesar 38,106 ton C/ha (Purwanto et al. 2012), hutan rakyat Desa Buana Sakti, Kabupaten Lampung Timur berjumlah 95,03 ton C/ha (Rizki et al. 2016), dan hutan kemasyarakatan Nanggala, Kabupaten Toraja Utara dengan pendugaan total simpanan 504,63 ton C/ha (Muin et al. 2018), Nilai tersebut mengindikasikan bahwa pengelolaan hutan rakyat Desa Sambak tergolong dalam kondisi awal dengan komposisi yang relatif masih muda. Namun, tentu terdapat tren yang positif karena adanya kepedulian masyarakat dalam menanam tanamantanaman yang mempunyai simpanan karbon tinggi.

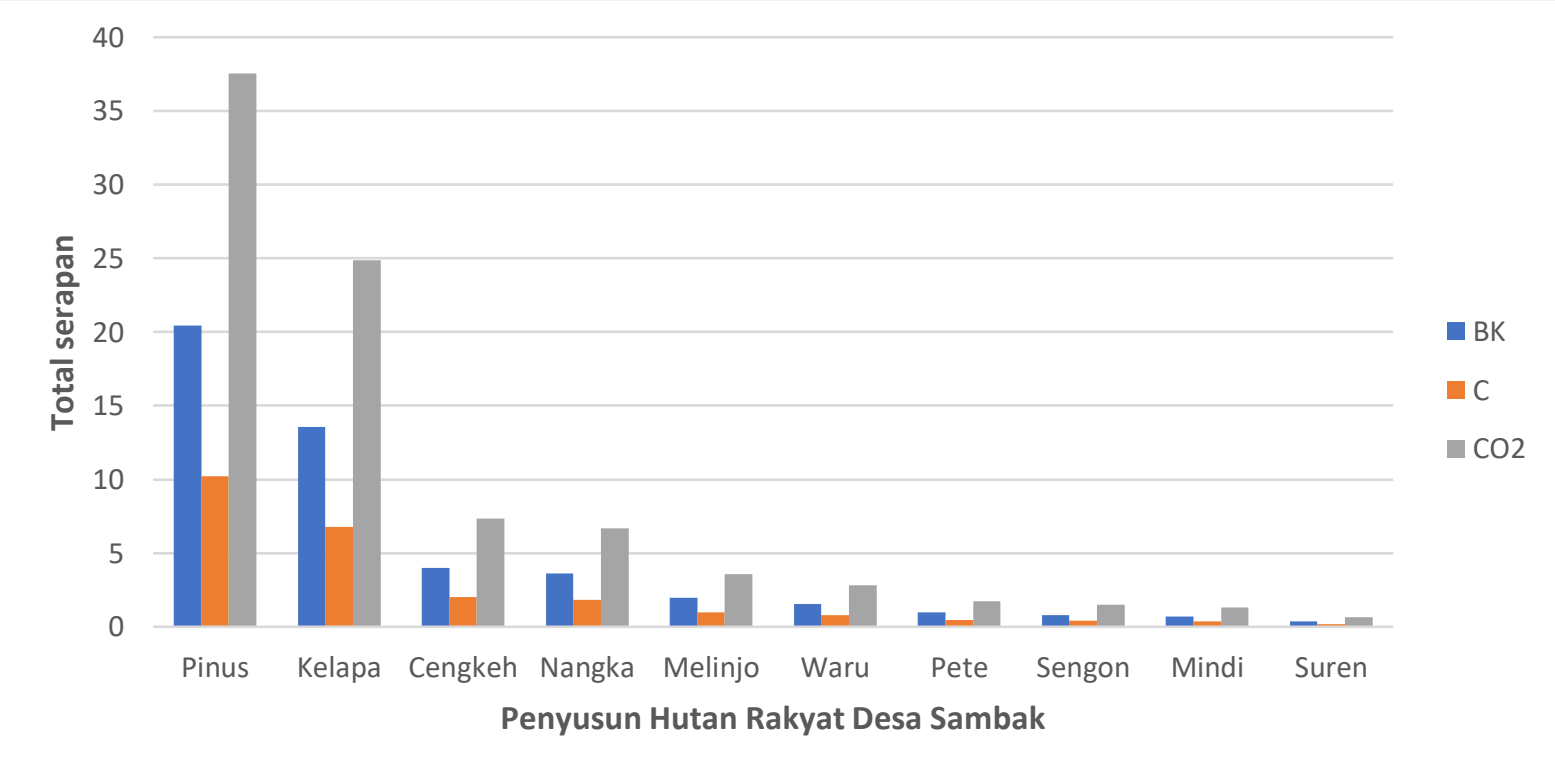

Gambar 4. Daftar 10 spesies yang mempunyai total serapan karbon tertinggi di hutan rakyat Desa Sambak

Gambar 4 juga menunjukkan bahwa Pinus memiliki nilai tertinggi dalam taksiran simpanan karbon yaitu sebesar 10,22 ton C/ha. Nilai tersebut berbeda dengan potensi tertinggi simpanan karbon pada di hutan Nglanggeran yaitu pada Mahoni 23,119 ton C/ha (Purwanto et al. 2012). Kondisi tersebut disebabkan karena Pinus didalam praktik hutan rakyat Desa Sambak merupakan tanaman 
yang sudah berumur tua, cenderung memiliki diameter dan tinggi yang lebih besar dibandingkan yang lainnya, meskipun bukan termasuk yang memiliki INP tinggi. Hal tersebut juga mengindikasikan bahwa Pinus dan tanaman kayu keras lainnya mempunyai nilai potensi simpanan karbon yang tinggi untuk dapat diterapakan dalam praktik-praktik hutan rakyat dengan tetap memperhatikan kesesuaian habitatnya. Selain itu, spesies-spesies tersebut juga memberikan fungsi tutupan tajuk yang sesuai untuk tanaman pengisi/sela pada praktik hutan rakyat.

Perbedaan nilai karbon yang tersimpan di setiap individu ditentukan oleh diameter dan berat jenis tanaman. Hairiah \& Rahayu (2007) mengungkapkan bahwa hutan yang terdiri atas pohon-pohon yang mempunyai nilai kerapatan kayu tinggi maka biomasanya akan lebih tinggi dibandingkan dengan komunitas hutan yang mempunyai pohon-pohon dengan nilai kerapatan kayu rendah. Markum et al. (2013) mengungkapkan bahwa simpanan karbon pada praktik hutan rakyat berkontribusi secara nyata (16-23\%) dalam pengurangan emisi karbon.

Potensi simpanan karbon pada hutan rakyat juga mengindikasikan bahwa keberadaan hutan rakyat tidak hanya bermanfaat untuk menunjang ekonomi masyarakat tetapi memiliki manfaat lain, antara lain sebagai penjaga ekosistem dengan menyerap emisi karbon dan menyimpan karbon. Oleh karena itu, pengembangan hutan rakyat perlu dikembangkan dan diintensifkan dalam upaya mengurangi dampak pemanasan global dan pemberdayaan sosial ekonomi masyarakat.

\section{Peluang pemanfaatan hutan rakyat Desa Sambak}

Penyeimbangan kepentingan ekonomi dan ekologi merupakan kunci utama dalam pengelolaan hutan rakyat. Pemilihan komposisi vegetasi penyusun hutan rakyat akan menentukan dampak dari hutan rakyat ke depannya. Qurniati \& Harianto (2012) mengungkapkan bahwa pemilihan tanaman yang sesuai dengan karakteristik lahan akan memberikan dampak positif terhadap tanah. Petani pengelola hutan rakyat biasanya memilih tanaman penyusun di lahannya berdasarkan lamanya produksi dan hasil yang akan diperoleh. Kondisi tersebut juga selaras dengan pendapat Widiarti \& Prajadinata (2008) yang menyatakan bahwa pemilihan komposisi penyusun vegetasi hutan rakyat sangat dipengaruhi oleh faktor pendapatan petani, kontinuitas produksi, daur panen, daur pemeliharaan, dan faktor interaksi dengan tanaman pengisi/tanaman pertanian.

Pada umumnya, masyarakat memilih tanaman berdaur pendek seperti sengon. Sengon merupakan spesies tanaman yang banyak ditanam pada lahan milik rakyat, khususnya di Jawa (Jariyah \& Wahyuningrum 2008). Sengon juga merupakan spesies tanaman berdaur pendek (fast growing), kayunya multiguna (multi purposes), dan tidak membutuhkan syarat pertumbuhan yang khusus (Santoso 1992; Zulkarnaen \& Suryanto 2013). Zulkarnaen \& Suryanto (2013) menyebutkan bahwa keberadaan sengon dengan karakteristik tajuk yang ringan memberikan dampak positif terhadap produksi tanaman pengisi. Hairiah et al. (2003) menyatakan bahwa praktik hutan rakyat dengan persentase tutupan tajuk ringan mampu mengurangi intensitas cahaya matahari berkisar 30$50 \%$.

Berdasarkan karakteristik lahan dan ketinggian tempat, tanaman yang cocok sebagai pengisi/sela dalam praktik hutan rakyat Desa Sambak adalah tanaman kopi. Meskipun nilai INP kopi tergolong kecil (6,66\%), namun jika dibandingkan dengan tanaman buah lainnya maka kopi merupakan pilihan yang tepat. Selain bermanfaat secara ekonomi, tanaman kopi juga dapat berfungsi sebagai penekan laju erosi (Budidarsono \& Wijaya 2004; Bizambi 2017). Nilai ekonomi yang dihasilkan dari Kopi relatif tinggi, contohnya di hutan rakyat Kabupaten Kepahiang, Provinsi Bengkulu, Kopi memberikan nilai kontribusi ekonomi sebesar Rp. 6.501.553/ha per tahun. Prasetyo (2004) juga menambahkan bahwa pemilihan sengon sebagai tanaman utama dalam praktik hutan rakyat mampu meningkatkan produksi hasil dari tanaman sela/pengisi, karena sengon memberikan naungan $35-70 \%$ sehingga perkembangan tanaman sela/pengisi dapat optimal. Hal tersebut juga selaras dengan Siregar et al. (2007) yang mengungkapkan bahwa pemilihan tanaman sengon pada praktik pengelolaan hutan rakyat di Jawa mempunyai nilai ekonomi yang tinggi.

Adapun spesies lainnya yang sering ditemukan dalam praktik hutan rakyat yaitu Mahoni. Pemilihan Mahoni sebagai salah satu komoditas utama hutan rakyat didasarkan atas 
kebutuhan kayu untuk keperluan pembangunan rumah (Maryudi \& Nawir 2017). Jariyah \& Wahyuningrum (2008) menjelaskan bahwa meskipun mahoni termasuk dalam spesies berdaur lama (slow growing), namun spesies ini sering dimanfaatkan dalam praktik hutan rakyat di Jawa selain jati yang berdaur lama. Adapun lama daur mahoni yang mencapai 40 tahun mengharuskan pemilihan tanaman perkebunan/pertanian dalam sistem pengelolaan hutan rakyat harus tepat dan tahan terhadap naungan karena penutupan tajuk mahoni tergolong berat.

\section{KESIMPULAN}

Berdasarkan penelitian ini dapat disimpulkan sebagai berikut:

1. Vegetasi hutan rakyat Desa Sambak tergolong dalam kelas yang relatif muda yang didominasi oleh pohon pada fase tiang. Komposisi vegetasi yang dominan adalah Sengon (Falcataria falcata), Mahoni (Swietenia macrophylla), dan Kelapa (Cocos nucifera), dan Nangka (Artocarpus heterophyllus).

2. Potensi simpanan karbon di hutan rakyat Desa Sambak berjumlah 24,53 ton C/ha dengan nilai simpanan karbon tertinggi pada Pinus (Pinus merkusii).

\section{UCAPAN TERIMA KASIH}

Penulis mengucapkan terima kasih kepada Dr. Priyono Suryanto (Dosen Fakultas Kehutanan UGM), Pak Dahlan (Kepala Desa Sambak), dan Pak Muhjuri (Aparat Desa Sambak) atas arahan dan perijinan yang diberikan untuk melakukan penelitian ini. Angga, Kiya, Dea, Jodi, dan Yuslina telah membantu dalam pengambilan data di lapangan. Prof. Dr. Rochadi Abdulhadi, sebagai pembimbing teknis penulisan pada Diklat Jabatan Fungsional Peneliti Tingkat I Gelombang 2, April 2015, yang telah memberikan petunjuk dalam penulisan naskah KTI. Terima kasih juga disampaikan kepada para mitra bestari yang telah banyak memberikan masukan dan saran untuk memperbaiki naskah ini.

\section{DAFTAR PUSTAKA}

Alviya I, Sakuntaladewi N, Hakim I. 2007. Pengembangan sistem pengelolaan hutan rakyat di Kabupaten Pandeglang. Jurnal Pusat Penelitian Sosial Ekonomi dan Kebijakan Kehutanan 7(1): 45-58.

Awang SA, Wiyono EB, Sadiyo S. 2007. Unit Manajemen Hutan Rakyat: Proses Kontruksi Pengetahuan Lokal. Banyumili Art Network bekerja sama dengan Pusat Studi Hutan Rakyat (PKHR) Universitas Gadjah Mada, Yogyakarta.

Bizambi B. 2017. Analisis finansial pada sistem agroforestry di Kelurahan Keban Agung, Kecamatan Bermani Ilir, Kabupaten Kepahiang. Skripsi, Fakultas Pertanian, Universitas Bengkulu.

Budidarsono S, Wijaya K. 2004. Praktik konservasi dalam budidaya kopi robusta dan keuntungan petani. Agrivita 26(1): 107-117.

Daniel TW, Helms JA, Baker F. 1979. Principles of Silviculture. Mc Graw-Hill, New York.

Hairiah K, Dewi S, Agus F, Velarde S, Ekadinata A, Rahayu S, van Noordwijk $M$. 2011. Measuring carbon stocks: across land use systems: a manual. Published in close cooperation with Brawijaya University and ICALRRD (Indonesian Center for Agricultural Land Resources Research and Development. World Agroforestry Centre, Southeast Asia Region, Bogor.

Hairiah K, Rahayu S. 2007. Pengukuran karbon tersimpan di berbagai macam penggunaan lahan. World Agroforestry Centre. Southeast Asia Region, Bogor.

Hairiah K, Sunaryo, Widianto. 2003. Sistem agroforestri di Indonesia. World Agroforestry Centre. Southeast Asia Region, Bogor.

Indrajaya Y, Sudomo A. 2016. Karbon tersimpan dalam biomassa hutan rakyat jamblang di Kabupaten Bantul dan Gunung Kidul, Yogyakarta. Prosiding SNaPP: Sains dan Teknologi. Universitas Islam Bandung.

IPCC. 2006. Guidelines for National Greenhouse Gas Inventories: References Manual. Paris.

Irmasari I, Edy N, Ramli R. 2018. Pengelolaan hutan rakyat berbasis agroforestri untuk meningkatkan kesejahteraan petani di 
sekitar kawasan Taman Nasional Lore Lindu Sulawesi Tengah. Jurnal Pengabdian Pada Masyarakat 6(10): 89-100.

Ivando D, Banuwa IS, Bintoro A. 2019. Karbon tersimpan pada berbagai tipe kerapatan tegakan di hutan rakyat Desa Sukoharjo I kecamatan Sukoharjo kabupaten Pringsewu. Jurnal Belantara 2(1): 53-61.

Jariyah N, Wahyuningrum N. 2008. Karakteristik hutan rakyat di Jawa. Jurnal Penelitian Sosial dan Ekonomi Kehutanan 5(1): 43-56.

Jones. 1979. Topics in Applied Geography Vegetation Productivity. Longman London and NewYork.

Ketterings QM, Coe R, van Noordwijk M, Palm CA. 2001. Reducing uncertainty in the use of allometric biomass equations for predicting above-ground tree biomass in mixed secondary forests. Forest Ecology and Management 146(1-3): 199-209.

Markum M, Soesilaningsih EA, Suprayogo, D, Hairiah K. 2013. Contribution of agroforestry system in maintaining carbon stocks and reducing emission rate at jangkok watershed, Lombok Island. Journal of Agricultural Science 35(3): 207-217.

Maryudi A, Nawir AA. 2017. Hutan Rakyat di Simpang Jalan. Gadjah Mada University Press, Yogyakarta.

Mirbach V. 2000. Carbon budget accounting at the forest management unit level: An overview of issues and methods. Canada's Model Forest Program, Natural Resources Canada, Ottawa.

Mueller-Dombois, Ellenberg H. 1974. Aims and Methods of Vegetation Ecology. Blackburn Press Caldwell, New Jersey.

Muin AVF, Millang S, Rijal S. 2018. Potensi biofisik hutan kemasyarakatan Nanggala. Jurnal Hutan dan Masyarakat 10(1): 145-153.

Nair PR, Nair VD, Kumar BM, Haile SG. 2009. Soil carbon sequestration in tropical agroforestry systems: a feasibility appraisal. Environmental Science and Policy 12(8): 1099-1111.

Nugroho D. 2014. Menghitung Cadangan Karbon di Hutan Rakyat Panduan bagi Para Pendamping Petani Hutan Rakyat. ARuPA. Yogyakarta
Prasetyo 2004. Budidaya kapulaga sebagai tanaman sela pada tegakan sengon. Jurnal IImu-IImu Pertanian Indonesia 6(1): 22 - 31.

Purwanto RH, Rohman R, Maryudi A, Yuwono T, Permadi DB, Sanjaya M. 2012. Potensi biomasa dan simpanan karbon jenis-jenis tanaman berkayu di hutan rakyat Desa Nglanggeran, Gunungkidul, Daerah Istimewa Yogyakarta. Jurnal IImu Kehutanan 6(2): 128-141.

Purwanto RH, Silaban M. 2011. Inventore Biomasa dan Karbon Jenis Jati (Tectona grandis L.f.) di hutan rakyat Desa Jatimulyo, Karanganyar. Jurnal IImu Kehutanan 5(1): 40-50.

Qurniati R, Harianto SP. 2012. Pemilihan jenis tanaman dalam rangka mendukung konservasi air. Prosiding Seminar Agroforestri III Pembaharuan Agroforestri Indonesia: Benteng Terakhir Kelestarian, Ketahanan Pangan, Kesehatan dan Kemakmuran. Balai Penelitian Teknologi Agroforestri, Kementerian Kehutanan RI.

Rancangan Pembangunan Jangka Menengah Desa (RPJMD) Nomor 188.4/02/DSXI/2004 Mewujudkan Desa Agro Wana Wisata untuk kemandirian dan kesejahteraan. Pemerintah Desa Sambak, Magelang.

Rizki GM, Bintoro A, Hilmanto R. 2016. Perbandingan emisi karbon dengan karbon tersimpan di hutan rakyat Desa Buana Sakti Kecamatan Batanghari Kabupaten Lampung Timur. Jurnal Sylva Lestari 4(1): 89-96.

Santoso HD. 1992. Budidaya sengon. Percetakan Kanisius: Yogyakarta.

Siarudin M, Indrajaya Y. 2014. Struktur tegakan dan cadangan karbon hutan rakyat pola agroforestri manglid (Manglieta glauca $\mathrm{BI}$.) di Tasikmalaya, Jawa Barat. Jurnal Penelitian Agroforestry 2(1): 45-56.

Simon H. 2001. Pengelolaan hutan bersama masyarakat. BIGRAF Publishing, Yogyakarta.

Siregar UJ, Rachmi A, Massijaya MY, Ishibashi N, Ando K. 2007. Economic analysis of sengon Paraserianthes falcataria community forest plantation, a fast growing species in East Java, Indonesia. Forest Policy and Economics 9(7): 822-829. 
Soegianto A. 1994. Ekologi kuantitatif: Metode Analisis Populasi dan Komunitas. Penerbit Usaha Nasional, Jakarta.

Sudomo A, Hani A. 2014. Produktivitas talas (Colocasia esculenta L. Shott) di bawah tiga jenis tegakan dengan sistem agroforestri di lahan hutan rakyat. Jurnal IImu Kehutanan 8(2): 100-107.

Suprapto E. 2010. Hutan Rakyat: Aspek Produksi, Ekologi dan Kelembagaan. Lembaga ARuPA, Yogyakarta.

Ulfah M, Rohmawati I. Aprilia D. 2017. Pemaknaan masyarakat promasan tentang fungsi ekologis hutan di wilayah Gunung Ungaran. Bioma: Jurnal IImiah Biologi 6(1): 22-32.

Undang-Undang Republik Indonesia Nomor 41 Tahun 1999 tentang Kehutanan.

Wibowo A, Samsoedin I., Nurjahjawilasa, Subarudi, Muttaqin Z. 2013. Petunjuk praktis menghitung cadangan karbon hutan. Pusat penelitian dan Pengemabangan Perubahan Iklim dan kebijakan. Kementerian Kehutanan, Jakarta.

Widiarti A, Prajadinata S. 2008. Karakteristik hutan rakyat pola kebun campuran. Jurnal Penelitian Hutan dan Konservasi Hutan Alam 5(2): 145-156.

Widiarti A. 2015. Kontribusi hutan rakyat untuk kelestarian lingkungan dan pendapatan. Prosiding Seminar Nasional. Masyarakat Biodiversitas Indonesia. Universitas Sebelas Maret, Solo.

Zahabu E. 2006. Handei Village Forest Reserve, Tanzania. In: Murdiyarso D, Skutsch M. (eds.) Community forest management as a carbon mitigation option: case studies. CIFOR, Bogor.

Zulkarnaen RN, Suryanto P. 2013. Variasi tajuk dalam sistem agroforestri berbasis kopisengon di Desa Sambak, Kajoran, Kabupaten Magelang. Skripsi, Fakultas Kehutanan, Universitas Gadjah Mada. 